\title{
Cytotoxic effects of duloxetine on MKN45 and NIH3T3 cell lines and genotoxic effects on human peripheral blood lymphocytes
}

\author{
Melika HASSANI ${ }^{1}$, Nasrin GHASSEMI-BARGHI ${ }^{2}$, Mona MODANL00², Abbas MOHAMMADPOUR ${ }^{2}$ and \\ Mohammad SHOKRZADEH ${ }^{2}$
}

Received 28/6/2019

\begin{abstract}
Background - Gastric cancer is the second leading cause of cancer-related death globally. Unfortunately, the survival rate of the gastric cancer patients who underwent chemotherapy following surgery has been less than a half. Besides, chemotherapy has many side effects. Current evidence suggests that some antidepressants like duloxetine have growth-inhibiting effects against a number of cancer cell lines. Objective - Thus, the aim of this study was to determine the cytotoxic and genotoxic effects of duloxetine on gastric cancer. Methods - In this regard, the cytotoxicity and genotoxicity of duloxetine were investigated in MKN45 and NIH3T3 cell lines by MTT assay and on peripheral blood lymphocytes by MN assay. For this purpose, cells were cultured in 96 wells plate. Stock solutions of duloxetine and cisplatin were prepared. After cell incubation with different concentrations of duloxetine (1, 10, 25, 50, 100 and $200 \mu \mathrm{L})$, MTT solution was added. For micronucleus assay fresh blood was added to RPMI culture medium 1640 supplemented, and different concentrations of duloxetine (1, 10, 25, 50, 100 and $200 \mu \mathrm{L})$ were added. Results - The cytotoxicity

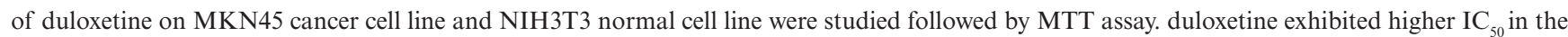
MKN45 cells in comparison with the NIH3T3 cells. In addition, genotoxic effect of duloxetine was evaluated by micronucleus assay. The results revealed that duloxetine induced more DNA damage at 100 and $200 \mu \mathrm{M}$ and no significant difference at $200 \mu \mathrm{M}$ with respect to cisplatin, but it had less genotoxic effects at 100 and $50 \mu \mathrm{M}$ concentrations. Conclusion - Although, in this study, duloxetine had less genotoxicity than cisplatin in concentrations under $200 \mu \mathrm{M}$ and showed cytotoxic effects as well, due to its $\mathrm{IC}_{50}$, it cannot be considered as a better choice for gastric cancer therapies with respect to cisplatin as a common anticancer drug.
\end{abstract}

HEADINGS - Stomach neoplasms, drug therapy. Antineoplastic agents. Antipsychotic agents. Duloxetine hydrochloride, toxicity. Cisplatin.

\section{INTRODUCTION}

Gastric cancer is believed to be the fourth most common type of cancer; it is also the second leading cause of cancer-related death globally. Unfortunately, the survival rate of the gastric cancer patients who underwent chemotherapy following surgery has remarkably been less than a half ${ }^{(1)}$. Furthermore, chemotherapy has many side effects ${ }^{(2)}$. Current evidence suggests that some antidepressants have growth-inhibiting effects against a number of cancer cell lines and they are now reported to have potent anti-cancer properties against a wide variety of malignancies in addition to their antipsychotic effects ${ }^{(3,4)}$. Today, duloxetine is a widely used antidepressant worldwide with the advent of drug therapy and the emergence of new antidepressant drugs by the various recent research ${ }^{(5,6)}$. The neuronal reuptake of serotonin 5-Hydroxytryptamine, 5-HT) and norepinephrine are usually inhibited by duloxetine $((+)-(\mathrm{S})$-N-Methyl- $\gamma-(1-n a p h t h y l o x y)$ -2-thiophenylpropylamine), so in order to manage diabetic peripheral neuropathic pain, fibromyalgia, and chronic musculoskeletal pain, duloxetine is prescribed in the United States ${ }^{(7)}$. While, it is noticeable that in recent years, duloxetine has shown dose-dependent cytotoxicity on some cancer cell lines such as
MCF-7 and HepG2 and it was suggested that this agent should be further evaluated for potential use $\mathrm{e}^{(3,8,9)}$. MTT assay is one of the most widely used methods for cytotoxicity screening ${ }^{(10)}$. On the other hand, due to the limited data on the genotoxicity of drugs, the number of drugs that can actually be safely used has been decreased. Thus, in vitro genotoxicity tests are used to detect materials that damage genetic material and lead to DNA break, mutations, chromosomal breaks, or impaired ability to repair DNA, which is an important indicator of carcinogenesis ${ }^{(9,11-13)}$. One of the genotoxic assays which is widely applicable in different cell types, is internationally validated, has potential for automation and is predictive for cancer is micronucleus $(\mathrm{MN})$ assay ${ }^{(14,15)}$. Due to the fact that common anticancer drugs such as cisplatin, doxorubicin, docetaxel, and etc. have many side effects, it is now highly desirable to build and use new drugs that have less toxicity to normal cells and high toxicity to malignant cells ${ }^{(2,16-19)}$. The anticancer effects of duloxetine on some cancer cell lines have been investigated, but in gastric cancer MKN45 cancer cell line has not yet been studied ${ }^{(20-25)}$. Therefore, the purpose of this study is to examine the effects of duloxetine on metastatic cells. In this regard, its cytotoxicity and genotoxicity was investigated in MKN45 and NIH3T3 cell lines and on peripheral blood lymphocytes. 


\section{METHODS}

\section{Cell culture}

NIH3T3 and MKN45 Cell lines (Pasteur Institute, Tehran, Iran) were cultured in Dulbecco's Modified Eagle Medium (DMEM) (GIBCO, Berlin, Germany) with 10\% fetal bovine serum (FBS) (Gibco-BRL, Germany) and $100 \mu \mathrm{g} / \mathrm{mL}$ streptomycin (Gibco-BRL, Germany) and $100 \mathrm{IU} / \mathrm{mL}$ penicillin (Gibco-BRL, Germany). Cell cultures were adjusted to allow for exponential growth.

\section{Cell viability assay (MTT assay)}

NIH3T3 and MKN45 cell lines ( $10^{4}$ cells) were cultured in $200 \mu \mathrm{L}$ DMEM/F12 medium containing $10 \%$ bovine serum in 96 wells plate and incubated at $37^{\circ} \mathrm{C}$ for $24 \mathrm{~h}$. Stock solutions of duloxetine and cisplatin (a platinum coordination complex with potent anti-neoplastic activity induces apoptosis in cancer cells, possibly via caspase-3 activation) were prepared in $1 \%$ DMSO and phosphate buffered saline (PBS), respectively. Twenty- $\mu \mathrm{L}$ of MTT solution $(5 \mathrm{mg} / \mathrm{mL})$ was added to each well following $48 \mathrm{~h}$ incubation with different concentrations of duloxetine $(1,10,25$, 50,100 and $200 \mu \mathrm{L}$ ). The optical density (OD) of the MTT reaction was measured on a microplate ELISA reader at $570 \mathrm{~nm}$. All experiments were repeated two times and each treatment was run in triplicate. The percentage of cell viability was calculated using the equation: [mean (OD) of treated cells/mean OD of control cells $(1 \% \mathrm{DMSO})] \times 100^{(26)}$.

\section{Micronucleus assay}

Fresh blood was collected from 10 healthy, no smoking, no alcoholic, male donors aged between $25-35$ years by venipuncture in heparinized falcons. $0.5 \mathrm{~mL}$ of whole blood was added to $4.5 \mathrm{~mL}$ of Roswell Park Memorial Institute (RPMI) culture medium 1640 supplemented with $10 \%$ fetal bovine serum containing L-glutamine, antibiotics, and phytohemagglutinin (PHA), and different doses of duloxetine $(1,10,25,50,100$ and $200 \mu \mathrm{L})$. The binucleated lymphocytes were harvested $28 \mathrm{~h}$ after adding Cytochalasin B (Cyt-B) (Sigma, Missouri, USA); they were treated by hypotonic $\mathrm{KCl}(0.075 \mathrm{M})$ to red blood cell $(\mathrm{RBC})$ lysis. Then fixative solution (methanol: acetic acid =6:1) was added to the cells prior to slide preparation and staining. For slide preparation, 2-3 drops of cell suspension were thrown on a clean slide. The slides were stained with Giemsa solution (4\%) for 7-10 mins. They were observed at $40 \times$ and $100 \times$ magnifications using a light microscope to estimate mitotic index (the cells with 2 or more nuclei per 1000 observed cells) and micronuclei frequency (the number of micronuclei in 1000 binucleated cells) are lymphocytes that were once divided by mitosis. The experiment was performed two times. Mitotic Index has a direct relation with cells' proliferative activity ${ }^{(27)}$.

\section{Statistical analysis}

One way analysis of variance and Tukey's honestly significant differences (HSD) test were used for multiple comparisons of data. $P$ value less than 0.05 was considered as significant. The $\mathrm{IC}_{50}$ (half maximal inhibitory concentration) values were calculated by PRISM software using nonlinear regression. Standard deviations represent average results of double experiments. The $\mathrm{IC}_{50}$ values were compared using the Student's $t$-test measuring the effectiveness of a substance to cause cell death or inhibit cell growth. Therefore, the lower amount of $\mathrm{IC}_{50}$ represents a higher toxicity of a compound, which leads to death or inhibition of cell growth.

\section{RESULTS}

\section{MTT assay}

The $\mathrm{IC}_{50}$ of duloxetine on MKN45 and NIH3T3 cell lines were examined using MTT assay. The $\mathrm{IC}_{50}$ of duloxetine on MKN45 cancer cell line was $40.41 \mu \mathrm{g} / \mathrm{mL}$ and on NIH3T3 cell line was $15.79 \mu \mathrm{g} / \mathrm{mL}$, which implies that the $\mathrm{IC}_{50}$ of duloxetine related to the NIH3T3 cell line was lower than the MKN45 cell line. The evaluated $\mathrm{IC}_{50}$ of cisplatin on MKN45 cell line was $12.49 \mu \mathrm{g} / \mathrm{mL}$ and on NIH3T3 cell line was $24.9 \mu \mathrm{g} / \mathrm{mL}$. A lower $\mathrm{IC}_{50}$ value is representative of the higher ability of a cytotoxic compound to cause cell death or inhibit cell growth ${ }^{(28)}$. It means that the inhibitory effect of growth and the most cytotoxicity of the drug are on the normal cell line in comparison with the cancer cell line. The results of the MKN45 cell line (TABLE 1 and FIGURE 1) demonstrated that duloxetine compared to the negative control group had more cytotoxic effects at $25,50,100,200 \mu \mathrm{M}$ and no significant difference at 1 and $10 \mu \mathrm{M}$ concentrations. Compared to the positive

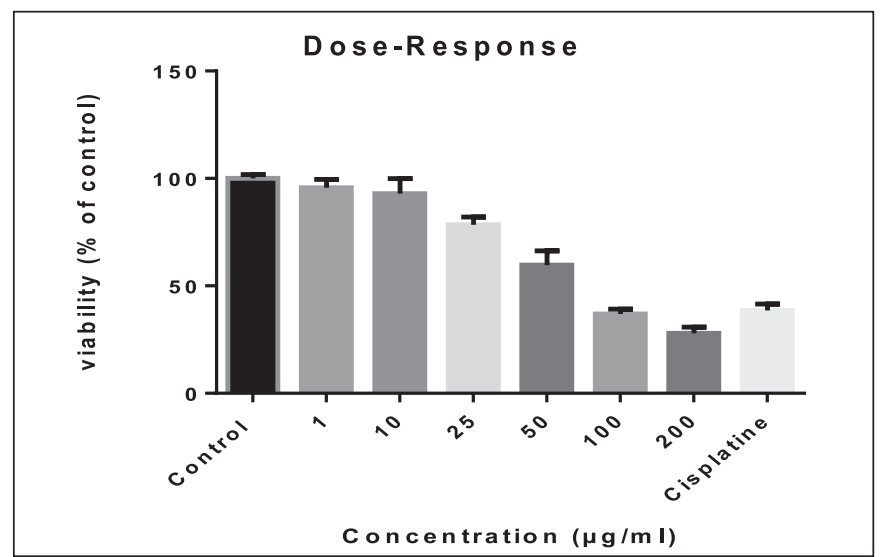

FIGURE 1. Effects of duloxetine on NIH3T3 cell viability \{a: significant difference compared to the negative control group; b: significant difference compared to the positive control group $(P<0.05)\}$.

TABLE1. Effect of duloxetine on MKN45 and NIH3T3 cell viability.

\begin{tabular}{|c|c|c|c|c|c|c|c|c|}
\hline Mean \pm SD & Control & 1 & 10 & 25 & 50 & 100 & 200 & Cisplatin \\
\hline $\begin{array}{l}\text { Effect of duloxetine } \\
\text { on MKN } 45 \text { cell } \\
\text { viability }\end{array}$ & $100.0 \pm 1.860$ & $95.73 \pm 3.889$ & $92.98 \pm 6.905$ & $78.44 \pm 3.628$ & $59.71 \pm 6.628$ & $36.98 \pm 2.235$ & $27.89 \pm 2.893$ & $38.57 \pm 2.996$ \\
\hline $\begin{array}{l}\text { Effect of duloxetine } \\
\text { on NIH3T3 cell } \\
\text { viability }\end{array}$ & $100.0 \pm 2.214$ & $95.81 \pm 1.069$ & $78.30 \pm 1.131$ & $50.77 \pm 1.324$ & $47.13 \pm 1.117$ & $44.41 \pm 1.390$ & $39.34 \pm 0.5759$ & $41.56 \pm 1.467$ \\
\hline
\end{tabular}


control group (cisplatin), it had less cytotoxic effects at 1, 10, 25, $50 \mu \mathrm{M}$ and no significant difference at 100 and $200 \mu \mathrm{M}(P<0.05)$. In addition, the results of the NIH3T3 cell line (TABLE 1 and FIGURE 2) showed that duloxetine in comparison with the negative control group was significantly different in all concentrations; it means that it had more cytotoxic effects in every data. Moreover, in comparison with the positive control group, it had less cytotoxic effects at $1,10,25,50 \mu \mathrm{M}$ and no significant difference at 100 and $200 \mu \mathrm{M}$ concentrations $(P<0.05)$.

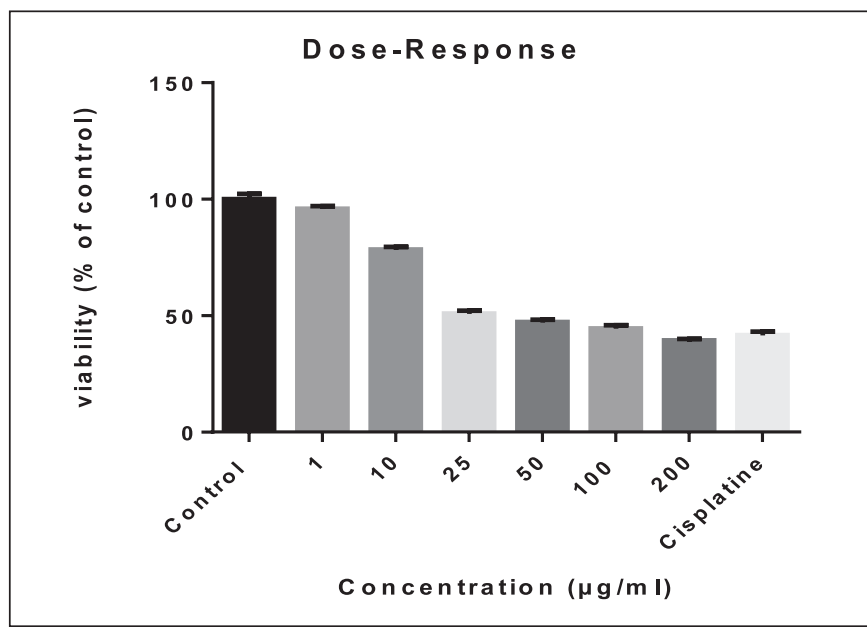

FIGURE 2. Effects of duloxetine on NIH3T3 cell viability \{a: significant difference compared to the negative control group; b: significant difference compared to the positive control group $(P<0.05)\}$.

\section{Micronucleus assay}

The genotoxic effects of duloxetine were studied based on the number of MN produced in peripheral blood lymphocytes following treatment with different concentrations of duloxetine (TABLE 2 and FIGURE 3). Results showed that the MN number was relatively increased based on the increase in the duloxetine concentration. Fifty- $\mu \mathrm{M}$ concentration of duloxetine did not produce any significant difference in $\mathrm{MN}$ number relative to the control group. While, 100 and $200 \mu \mathrm{M}$ concentrations of duloxetine significantly increased the number of $\mathrm{MN}$. Comparison of different concentrations of duloxetine and cisplatin showed that treatment of lymphocytes with 50 and $100 \mu \mathrm{M}$ of duloxetine significantly decreased the number of $\mathrm{MN}$. Two hundred- $\mu \mathrm{M}$ concentration of duloxetine did not produce any significant difference in $\mathrm{MN}$ number relative to the cisplatin $(P<0.05)$.

\section{DISCUSSION}

In this study, the cytotoxic effect of duloxetine on MKN45 gastric cancer cell line was investigated and compared to NIH3T3 normal cell line by MTT assay. The NIH3T3 cell line used in this study is the murine embryonic fibroblast, which is a standard and reliable source for these studies. Moreover, the genetic damage

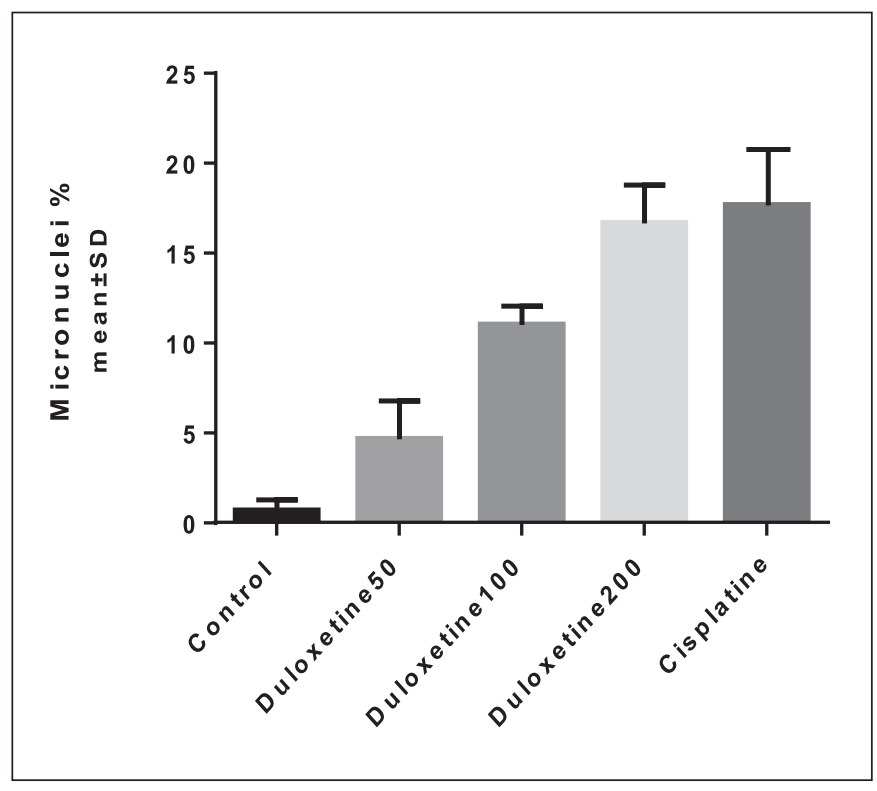

FIGURE 3. Micronuclei frequency in different concentrations of duloxetine a a: significant difference compared to the negative control group; b: significant difference compared to the positive control group $(P<0.05)\}$.

caused by this drug was also evaluated using MN assay. The $\mathrm{IC}_{50}$ of duloxetine on MKN45 cancer cell line and NIH3T3 cell line was calculated $40.41 \mu \mathrm{g} / \mathrm{mL}$ and $15.79 \mu \mathrm{g} / \mathrm{mL}$ respectively. However, the $\mathrm{IC}_{50}$ of cisplatin on MKN45 is $12.49 \mu \mathrm{g} / \mathrm{mL}$ and on $\mathrm{NIH} 3 \mathrm{~T} 3$ cell line is $24.9 \mu \mathrm{g} / \mathrm{mL}$. The lower $\mathrm{IC}_{50}$ value is representative of the higher ability of a cytotoxic compound to cause cell death or inhibit cell growth. As reported here, the dose-dependent cytotoxicity of duloxetine on MKN45 cancer cell line is consistent with some other researches ${ }^{(3,8)}$. The cytotoxic effects of the seven most commonly prescribed antidepressants was evaluated on MCF-7 breast cancer cell line ${ }^{(13,29)}$. Their results showed that Sertraline was the most potent drug in growth inhibition and had to be further analyzed ${ }^{(3)}$. The anti-tumor effects of four SSRIs and two SNRIs on HepG2 cells were compared as well, and the $\mathrm{IC}_{50}$ reduced relatively in the order of sertraline, paroxetine, duloxetine, fluvoxamine, escitalopram, and milnacipran ${ }^{(8,30)}$. Besides, the anti-viability effects of some drugs were fully proved on the proliferation of MKN45 cell line ${ }^{(20-24)}$. Nonetheless, by comparing the cytotoxic effects and the $\mathrm{IC}_{50}$ of duloxetine on MKN45 and NIH3T3 cell lines it was shown that the cytotoxic effects of duloxetine on NIH3T3 normal cell line was higher than MKN45 cancer cell line. Taken together, it seems that duloxetine in the concentrations presented in this research could not be considered as a better choice for MKN45 gastric cancer therapy. Additionally, we used lymphocytes in our in vitro studies to assess the potential genotoxic effect of duloxetine. Results from the micronucleus assay confirmed the ability of duloxetine to induce the formation of micronuclei. The induction of micronuclei is commonly used to evaluate the chromosomal damage. The cellular and tissue

TABLE2. Micronuclei frequency in different concentrations of duloxetine.

\begin{tabular}{lcccc}
\hline & Control & Duloxetine 50 & Duloxetine 100 & Duloxetine 200 \\
\hline Mean \pm SD & $0.6667 \pm 0.5774$ & $4.667 \pm 2.082$ & $11.00 \pm 1.000$ & $16.67 \pm 2.082$ \\
\hline
\end{tabular}


toxicity was observed in the increased therapeutic concentrations of duloxetine. duloxetine and its metabolites can bind DNA, causing damage that can result in chromosome breaks, micronucleus formation, and cell death. As evident, duloxetine induced DNA damage to human lymphocytes compared to the negative control group except at $50 \mu \mathrm{M}$ concentration. In addition, this drug had no significant difference with cisplatin at $200 \mu \mathrm{M}$ concentration, but it had a low genotoxicity at 100 and $50 \mu \mathrm{M}$ concentrations $(P<0.05)$. It confirmed that this drug is safe to be used at these concentrations. A recent report in mouse bone marrow was made to evaluate the capacity of three doses of duloxetine (2, 20, and 200 $\mathrm{mg} / \mathrm{kg}$ ). Their results indicated a moderate but significant increase of SCE (sister chromatid exchanges) with three concentrations tested, no effect regarding the mitotic index and a small reduction in the proliferation kinetics ${ }^{(5,31)}$. Also the possible genotoxic potential of duloxetine was explored by evaluating structural chromosomal aberrations, mitotic index, nuclear division index, index binucleation, number of cells (with one, two, three and four micronuclei) and the number of cells with nucleoplasmic bridges. As the positive control, Cyclophosphamide $(6 \mu \mathrm{g} / \mathrm{mL})$ and different concentrations of duloxetine (10-150 ng/mL) were applied on primary cultures of blood lymphocytes. Their results showed that the cultures incubated with duloxetine indices had lower scores suggesting a degree of the drug cytotoxicity. However, a significant increase in the presence of chromosomal aberrations and micronuclei was observed only by the concentrations of 100 and $150 \mathrm{ng} / \mathrm{mL}$. It should be noted these concentrations were close to the upper limit of the therapeutic range of the drug used in humans (Araújo, 2014). Our genotoxic studies were in line with the past studies earlier mentioned.

\section{CONCLUSION}

In conclusion, given that, this is the first time that cytogenetic study of duloxetine was evaluated and compared in MKN45 and NIH3T3 cell lines, based on the results of this study and comparisons with cisplatin in these concentrations, its value is low. Because the higher $\mathrm{IC}_{50}$ shows less power of sample in killing cells or inhibiting their growth. In addition, the genetic damage caused by duloxetine in blood lymphocytes had no significant difference with cisplatin at higher concentrations.

\section{ACKNOWLEDGEMENT}

This research was supported/partially supported by Sana institute of high education. We thank our colleagues from Mehdi Abbasi Roshan who provided insight and expertise.

\section{Authors' contribution}

Shokrzadeh M: study design and management. Modanloo M: MTT assay. Mohammadpour A: MN assay. Ghassemi-Barghi N: writing article. Hassani M: MN assay. All authors read and approve final manuscript.

\section{Orcid}

Melika Hassani. Orcid: 0000-0001-5762-4736.

Nasrin Ghassemi-Barghi. Orcid: 0000-0002-0673-4262.

Mona Modanloo. Orcid: 0000-0001-7526-4009.

Abbas Mohammadpour. Orcid: 0000-0003-2797-1766

Mohammad Shokrzadeh. Orcid: 0000-0002-0071-6530.

Hassani M, Ghassemi-Barghi N, Modanloo M, Mohammadpour A, Shokrzadeh M. Efeitos citotóxicos da duloxetina nas linhagens celulares MKN45 e NIH3T3 e efeitos genotóxicos em linfócitos sanguíneos periféricos humanos. Arq Gastroenterol. 2019;56(4):372-6.

RESUMO - Contexto - O câncer gástrico é a segunda principal causa de morte relacionada ao câncer globalmente. Infelizmente, a taxa de sobrevivência dos pacientes com câncer gástrico que se submeteram à quimioterapia após a cirurgia, tem sido inferior à metade. Além disso, a quimioterapia tem muitos efeitos colaterais. Evidências atuais sugerem que alguns antidepressivos como a duloxetina têm efeitos inibidores de crescimento contra um número de linhas de células cancerosas. Objetivo - Assim, o objetivo deste estudo foi determinar os efeitos citotóxicos e genotóxicos da duloxetina sobre o câncer gástrico. Métodos - A este respeito, a citotoxicidade e a genotoxicidade da duloxetina foram investigadas em linhas celulares MKN45 e NIH3T3 por ensaio de MTT e por ensaio de MN em linfócitos periféricos de sangue. Para este efeito, as células foram cultivadas em 96 placas. Soluções de estoque de duloxetina e cisplatina foram preparadas. Após incubação celular com diferentes concentrações de duloxetina (1, 10, 25, 50, 100 e $200 \mu \mathrm{L}$ ), a solução de MTT foi adicionada. Para o teste do micronúcleo o sangue fresco foi adicionado ao meio de cultura RPMI 1640 suplementado, e as concentrações diferentes de duloxetina (1, 10, 25, 50, 100 e $200 \mu \mathrm{L})$ foram adicionadas. Resultados - A citotoxicidade da duloxetina na linha celular cancerosa MKN45 e NIH3T3 linha celular normal foram estudadas e seguidas pelo ensaio de MTT. A duloxetina exibiu maior IC ${ }_{50}$ nas células MKN45 em comparação com as células NIH3T3. Além disso, o efeito genotóxico da duloxetina foi avaliado pelo ensaio de micronúcleos. Os resultados revelaram que a duloxetina induziu mais dano de DNA em 100 e $200 \mu \mathrm{M}$ e não houve diferença significativa em $200 \mu \mathrm{M}$ em relação à cisplatina, mas teve menos efeitos genotóxicos nas concentrações de 100 e $50 \mu \mathrm{M}$. Conclusão - Embora, neste estudo, a duloxetina tenha menos genotoxicidade do que a cisplatina em concentrações inferiores a $200 \mu \mathrm{m}$ e também tenha mostrado efeitos citotóxicos, devido ao seu $\mathrm{IC}_{50}$, não pode ser considerada como uma escolha terapêutica melhor para o câncer gástrico no que diz respeito à cisplatina como uma droga anticâncer comum.

DESCRITORES - Neoplasias gástricas, tratamento farmacológico. Antineoplásicos. Antipsicóticos. Cloridrato de duloxetina, toxicidade. Cisplatino. 


\section{REFERENCES}

1. Carcas LP. Gastric cancer review. J Carcinog. 2014;13:14.

2. Mazani M, Hadizadeh SH, Najafzadeh N, Amani M, Mansouri Torshizi H Anticancer effects of new palladium complexes on gastric cancer cell line. Jour Guilan Uni Med Sci. 2014. 23:72-9.

3. Bavadekar S, Panchal P, Hanbashi A, Vansal S. Cytotoxic effects of selective serotonin-and serotonin-norepinephrine reuptake inhibitors on human metastatic breast cancer cell line, MCF-7 (842.3). FASEB J. 2014;28(1 Supplement):842-3.

4. Huang J, Zhao D, Liu Z, Liu F. Repurposing psychiatric drugs as anti-cancer agents. Cancer Lett. 2018;419:257-65.

5. Madrigal-Bujaidar E, Álvarez-González I, Madrigal-Santillán EO, Morales-González JA. Evaluation of duloxetine as micronuclei inducer in an acute and a subchronic assay in mouse. Biol Pharm Bull. 2015;38:1245-9.

6. Araújo DBD. Genotoxicidade humana e fármacos antidepressivos: avaliação da duloxetina em culturas de linfócitos. Universidade Federal do Pará, 2014. pp.56.

7. Pergolizzi JV Jr, Raffa RB, Taylor R Jr, Rodriguez G, Nalamachu S, Langley P. A review of duloxetine $60 \mathrm{mg}$ once-daily dosing for the management of diabetic peripheral neuropathic pain, fibromyalgia, and chronic musculoskeletal pain due to chronic osteoarthritis pain and low back pain. Pain Pract. 2013;13:239-52.

8. Kuwahara J, Yamada T, Egashira N, Ueda M, Zukeyama N, Ushio S, Masuda S Comparison of the anti-tumor effects of selective serotonin reuptake inhibitors as well as serotonin and norepinephrine reuptake inhibitors in human hepatocellular carcinoma cells. Biol Pharm Bull. 2015;38:1410-4

9. Mohammadi H, Ghassemi-Barghi N, Malakshah O, Ashari S. Pyrethroid exposure and neurotoxicity: a mechanistic approach. Arh Hig Rada Toksikol. 2019; 70:74-89.

10. Ho WY, Yeap SK, Ho CL, Rahim RA, Alitheen NB. Development of multicellular tumor spheroid (MCTS) culture from breast cancer cell and a high throughput screening method using the MTT assay. PLoS One. 2012;7:e44640.

11. Ko H, Jeong Y, Kim M. Cytotoxicities and genotoxicities of cements based on calcium silicate and of dental formocresol. Mutat Res. 2017;815:28-34.

12. Ghassemi-Barghi N, Varshosaz J, Etebari M, Jafarian Dehkordi A Role of recom binant human erythropoietin loading chitosan-tripolyphosphate nanoparticles in busulfan-induced genotoxicity: Analysis of DNA fragmentation via comet assay in cultured HepG2 cells. Toxicol In Vitro. 2016;36:46-52.

13. Shokrzadeh M, Mohammadpour A, Hoseini V, Abediankenari S, Ghassemi-Barghi N, Tabari YS. Serum cytokine of IL-2, IL-10 and IL-12 levels in patients with stomach adenocarcinoma. Arq Gastroenterol. 2018;55:385-9.

14. Kirsch-Volders M, Plas G, Elhajouji A, Lukamowicz M, Gonzalez L, Vande Loock K, Decordier I. The in vitro MN assay in 2011: origin and fate, biological significance, protocols, high throughput methodologies and toxicological relevance. Arch Toxicol. 2011;85:873-99.

15. Shokrzadeh M, Ghassemi-Barghi N. Melatonin loading chitosan-tripolyphosphate nanoparticles: Application in attenuating etoposide-induced genotoxicity in HepG2 cells. Pharmacology. 2018;102:74-80

16. Coates A, Abraham S, Kaye SB, Sowerbutts T, Frewin C, Fox RM, Tattersall MH. On the receiving end- -patient perception of the side-effects of cancer chemotherapy. Eur J Cancer Clin Oncol. 1983;19:203-8.
17. Griffin AM, Butow PN, Coates AS, Childs AM, Ellis PM, Dunn SM, Tattersall $\mathrm{MH}$. On the receiving end V: patient perceptions of the side effects of cancer chemotherapy in 1993. Ann Oncol. 1996;7:189-95.

18. Florea AM, Büsselberg D. Cisplatin as an anti-tumor drug: cellular mechanisms of activity, drug resistance and induced side effects. Cancers (Basel). 2011;3:1351-71.

19. Chen Y, Wan Y, Wang Y, Zhang H, Jiao Z. Anticancer efficacy enhancement and attenuation of side effects of doxorubicin with titanium dioxide nanoparticles Int J Nanomedicine. 2011;6:2321-6.

20. Yoo HW1, Suh ME, Park SW. Synthesis and cytotoxicity of 2-methyl-4, 9-dihydro-1-substituted-1H-imidazo[4,5-g]quinoxaline-4,9-diones and 2,3-disubstituted-5,10-pyrazino[2,3-g]quinoxalinediones. J Med Chem. 1998;41:4716-22.

21. Hill BT, Whelan RD, Shellard SA, McClean S, Hosking LK. Differential cytotoxic effects of docetaxel in a range of mammalian tumor cell lines and certain drug resistant sublines in vitro. Invest New Drugs. 1994;12:169-82.

22. Shao QS, Ye ZY, Ling ZQ, Ke JJ. Cell cycle arrest and apoptotic cell death in cultured human gastric carcinoma cells mediated by arsenic trioxide. World J Gastroenterol. 2005;11:3451-6.

23. Bailly C, Qu X, Chaires JB, Colson P, Houssier C, Ohkubo M, et al. Substitution at the F-ring N-imide of the indolocarbazole antitumor drug NB-506 increases the cytotoxicity, DNA binding, and topoisomerase I inhibition activities. J Med Chem. 1999;42:2927-35.

24. Toiyama Y, Tanaka K, Konishi N, Mohri Y, Tonouchi H, Miki C, Kusunoki M. Administration sequence-dependent antitumor effects of paclitaxel and 5-fluorouracil in the human gastric cancer cell line MKN45. Cancer Chemother Pharmacol. 2006;57:368-75.

25. Ghassemi-Barghi N, Etebari M, Jafarian-Dehkordi A. Protective effect of amifostine on busulfan induced DNA damage in human hepatoma cells. Toxicol Mech Methods. 2017;27:52-7.

26. Abel SDA, Baird SK. Honey is cytotoxic towards prostate cancer cells but interacts with the MTT reagent: considerations for the choice of cell viability assay. Food Chem. 2018;241:70-8

27. Huang ZH, Li N, Rao KF, Liu CT, Huang Y, Ma M, Wang ZJ. Development of a data-processing method based on Bayesian k-means clustering to discriminate aneugens and clastogens in a high-content micronucleus assay. Hum Exp Toxicol. 2018:37:285-94.

28. Saravi SS, M Shokrzadeh, Hosseini Shirazi F. Cytotoxicity of Sambucus ebulus on cancer cell lines and protective effects of vitamins $\mathrm{C}$ and $\mathrm{E}$ against its cytotoxicity on normal cell lines. African Journal of Biotechnology, 2013;12:3360-5.

29. Mohammadi H, Ghassemi-Barghi N, Malakshah O, Ashari S. Pyrethroid exposure and neurotoxicity: a mechanistic approach. Arh Hig Rada Toksikol. 2019; 70:74-89.

30. Shokrzadeh M, Ghassemi-Barghi N. Genoprotective Effects of Amifostine agains Mitomycin C-induced Toxicity in Human Hepatoma Cells. Int J Cancer Res Ther 2018;3(2):1-5

31. Shokrzadeh M, Ghassemi-Barghi N. Antioxidant and Genoprotective Effects of Amifostine against Irinotecan Toxicity in Human Hepatoma Cells. Int J Cancer Res Ther. 2018;3(1):1-5. 